\title{
Technological properties of high alumina refractories with different phosphoric acid contents
}

\author{
Basel Nour El-Din Ali Shalaby ${ }^{1 *}$ D, Mohamed Saad El-Maghraby ${ }^{2}$ and Ali Ismail Mohamed Ismail ${ }^{1}$
}

\begin{abstract}
Background: High alumina refractory batches were prepared from Egyptian clay and imported China calcined bauxite. Three concentrations of phosphoric acid 3,5, and 7\%, were added to study their effects on some of their technological properties. Designed batches tend to form a composition of $76 \%$ alumina and $\sim 17 \%$ silica in addition to the other fluxing and alkali oxides. Chemical and mineralogical composition as well as density and plasticity of both clay and calcined bauxite was performed.

Results: Three batches of different phosphoric acid concentrations were fired at $1350^{\circ} \mathrm{C}$ for $1 \mathrm{~h}$. Densification parameters of the fired batches as well as the cold crushing strength and thermal shock resistance were carried out. The mineral composition and microstructure of the selected batch were done using XRD as well as SEM and EDAX. It is concluded that by increasing phosphoric acid percentages, the porosities slightly increase and the cold crushing strengths drastically decrease; however, densities and shrinkages exhibit no remarked effects.

Conclusions: The mineral composition of the selected fired batch exhibits mullite as a main phase with subordinate amount of corundum, while berlinite, quartz, and cristobalite are in less frequent contents. Microstructure of the selected batch ensures that mullite and corundum are the main mineral phases, in addition to minor phases of phosphate minerals. The fluxing and alkali oxides together with some alumina and silica form a liquid phase, which is responsible for the densification of the batch, while mullite and corundum are the essential formed minerals.
\end{abstract}

Keywords: Egyptian clay, High alumina refractories, Mullite, Corundum, Phosphoric acid

\section{Introduction}

Refractory materials are inorganic, non-metallic, and brittle crystalline solid materials, fired at optimum temperature according to their uses. They are used as face- and back-linings of industrial furnaces at high temperature for thermal insulations. They are classified according to their chemical composition and resistance to attack by the fired materials in contact under service conditions into acidic, neutral, and basic refractories (Shaw 1972 and Chesters 1973).

Aluminosilicate refractories, rich in silica, are belonging to acidic refractories, while those rich in alumina are essentially of neutral type. They are manufactured using refractory clays, which are composed of kaolinite

\footnotetext{
* Correspondence: baselshalaby@gmail.com

${ }^{1}$ Geological Sciences Department, National Research Centre, P.O. 12622, 33 El

Buhouth St. Dokki, Giza, Egypt

Full list of author information is available at the end of the article
}

clay mineral $\left(\mathrm{Al}_{2} \mathrm{O}_{3} \cdot 2 \mathrm{SiO}_{2} \cdot 2 \mathrm{H}_{2} \mathrm{O}\right)$, e.g., kaolins, fireclays, and ball clays. In addition, calcined $\mathrm{Al}_{2} \mathrm{O}_{3}$-rich raw materials are added to increase the alumina content and their refractory quality. The additives are mainly bauxite $\left(\mathrm{Al}_{2} \mathrm{O}_{3} \cdot 2 \mathrm{H}_{2} \mathrm{O}\right)$ and gibbsite $\left(\mathrm{Al}(\mathrm{OH})_{3}\right)$. These refractories include fireclay $\left(25-45 \% \mathrm{Al}_{2} \mathrm{O}_{3}\right)$, aluminous fireclay (45-65\% $\left.\mathrm{Al}_{2} \mathrm{O}_{3}\right)$, and high-alumina $\left(>72 \% \mathrm{Al}_{2} \mathrm{O}_{3}\right)$, respectively (Chesters 1974); Kingrey et al. 1976, and Sadik et al. 2014). Refractory oxides encompass a broad range of unary, binary, and ternary ceramic compounds that can be used in structural, insulating, and other applications.

Kaolinitic clays are considered as acidic refractories due to their $\mathrm{Al}_{2} \mathrm{O}_{3} / \mathrm{SiO}_{2}$ ratio, as well as their limited total fluxing and alkali oxide contents, namely, $\mathrm{Fe}_{2} \mathrm{O}_{3}$, $\mathrm{TiO}_{2}, \mathrm{CaO}, \mathrm{MgO}, \mathrm{Na}_{2} \mathrm{O}$, and $\mathrm{K}_{2} \mathrm{O}$. These clays include fireclays, ball clays, and kaolins (Grim 1968). Konta (1979) classified the kaolintic clays for ceramic industries according to their content of the total coloring 
oxides, i.e. $\mathrm{Fe}_{2} \mathrm{O}_{3}$ and $\mathrm{TiO}_{2}$, into two categories; the first grade (Seger 1 clays) contains less than $1.2 \%$ of the coloring oxides, e.g., China clay, which is suitable for production of white-ware ceramics, e.g., porcelain tableware and electrical insulators. Clays rich in kaolinite containing higher than $1.2 \%$ of total $\mathrm{Fe}_{2} \mathrm{O}_{3}$ and $\mathrm{TiO}_{2}$ are classified as Seger 2 clays, which are adequate for manufacturing colored and heavy clay-based ceramics and aluminosilicate refractories. The Egyptian kaolins and fireclays are mainly belonging to Seger 2 kaolinitic clays (Carniglia and Barna 1992, Routschka 2004, and Elmaghraby and Ismail 2016).

Phosphoric acid reacts with metal oxides to form salts which function as a bonding agent. Phosphoric acid and aluminum hydroxide react readily but alumina and phosphoric acid are only slowly reactive at ordinary temperature. When temperature rises, phosphoric acid undergoes dehydration and reacts with alumina to form mono aluminum phosphate, which starts above $127^{\circ} \mathrm{C}$ and continues till $427^{\circ} \mathrm{C}$. Between 732 and $1327^{\circ} \mathrm{C}$, aluminum orthophosphate is formed. Aluminum orthophosphate resembles silica in structure. It corresponds to quartz to form berlinite; it has ortho-polymorphs of cristobalite and tridymite forms (Schacht 2004, Sahnoun and Bouaziz 2012, and Luza et al. 2015). Refractory concretes based on binder modified with orthophosphoric acid improve the thermo-mechanical and physicochemical properties (Trepalina et al. 2016).

The scope of the present research is to prepare high alumina batch using Aswan clay and China calcined bauxite as well as to study the effect of different phosphoric acid percentages on the technological properties of the fired samples, through monitoring the densification parameters, cold crushing strengths, and thermal shock resistance. To achieve these parameters, chemical and mineralogical compositions of the starting materials were determined using XRF and $\mathrm{XRD}$, respectively. The plastic and liquid limits as well as the plasticity of the clay were determined to detect the amount of water required for making the clay as plastic material. The density of the used clay and the calcined bauxite was also measured. The high alumina batch was designed from the Egyptian clay and the China calcined bauxite according to their composition. Three different concentrations of 3,5 , and $7 \%$ of phosphoric acid were added to the preformed high alumina batch to form three different concentration batches. The designed batches of different phosphoric acid concentrations were fired at $1350{ }^{\circ} \mathrm{C}$ for $1 \mathrm{~h}$. The phase composition of the selected batch was done using XRD and a scanning electron microscope as well as EDAX. The densification parameters in terms of bulk density, apparent porosity, and linear shrinkage as well as cold crushing strength and thermal shock resistance were carried out.

\section{Methods}

Egyptian clay of Al-Ogybabe area, northeast of Aswan city, south of Egypt, and imported calcined bauxite were used to produce batch of high alumina refractories $\left(>72 \% \mathrm{Al}_{2} \mathrm{O}_{3}\right)$. The starting materials were received from Normatic Co. for building materials and refractories, Helwan, Cairo, Egypt. Phosphoric acid of 85\% concentration was received from El-Gomhoryia Company for chemicals.

High alumina refractory $>72 \% \quad \mathrm{Al}_{2} \mathrm{O}_{3}$ was processed using Egyptian raw clays and calcined bauxite. Calcined bauxite and Egyptian clay were crushed, ground to pass through 200 mesh. The used clay acts as a plastic-bonding material for the refractory batch. High alumina refractories were produced as standard from the corresponding calcined bauxite and clay by mixing with different percentages $(3,5$, and $7 \%$ ) of $85 \%$ phosphoric acid concentration, semi-dry, pressed, and dried. They were then fired for $1 \mathrm{~h}$ at $1350^{\circ} \mathrm{C}$.

Chemical and mineralogical compositions of the starting materials were carried out using XRF and $\mathrm{XRD}$, while the phase composition of the selected batch was done by using XRD and scanning electron microscope as well as EDAX.

The amount of water that rendered the raw clay material plastic (i.e., plasticity) was determined using the Atterberg method (BS 1377 1975). Bulk densities of the calcined bauxite and the clay raw material were determined. Densification parameters of the fired high alumina batch were investigated as bulk density and apparent porosity using the water displacement (Archimedes) method according to European Standard No. BS En No. 993-1/1993 (Serry et al. 2006).

Table 1 Chemical composition of the used materials

\begin{tabular}{lll}
\hline Oxide \% & Clay & Calcined bauxite \\
\hline $\mathrm{SiO}_{2}$ & 52.97 & 7.20 \\
$\mathrm{Al}_{2} \mathrm{O}_{3}$ & 29.07 & 85.39 \\
$\mathrm{TiO}_{2}$ & 1.48 & 4.08 \\
$\mathrm{Fe}_{2} \mathrm{O}_{3}$ & 3.92 & 2.45 \\
$\mathrm{CaO}$ & 0.50 & 0.07 \\
$\mathrm{MgO}$ & 0.20 & 0.16 \\
$\mathrm{Na}_{2} \mathrm{O}$ & 0.06 & 0.02 \\
$\mathrm{~K}_{2} \mathrm{O}$ & 0.28 & 0.27 \\
$\mathrm{SO}_{3}$ & 0.76 & - \\
$\mathrm{LOI}$ & 10.62 & - \\
Total & 99.86 & 99.64 \\
\hline
\end{tabular}




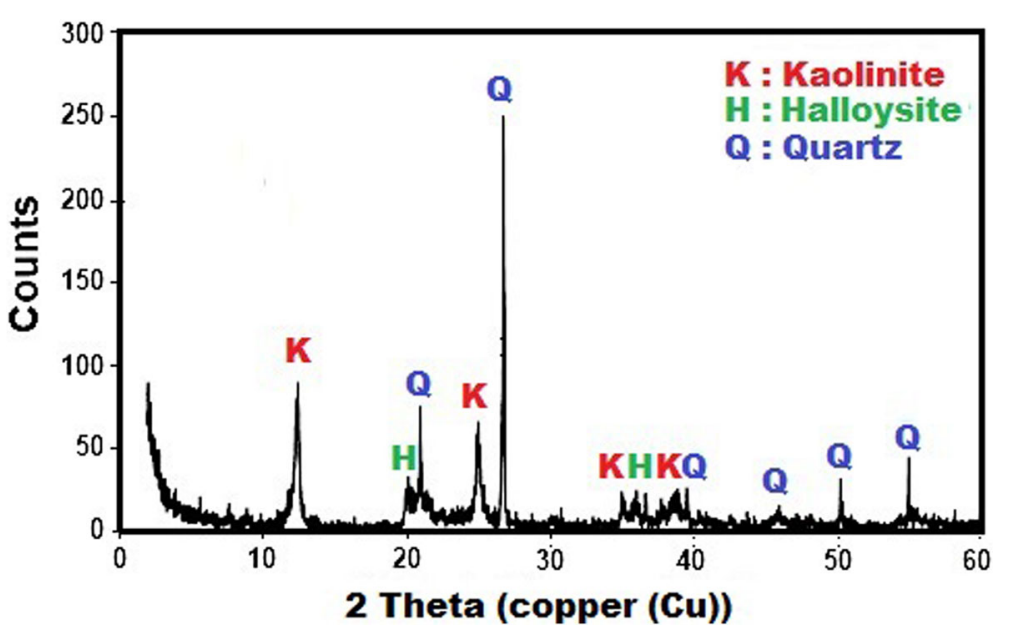

Fig. 1 XRD pattern of the raw clay material

Thermal shock resistance at $1000^{\circ} \mathrm{C}$ in terms of the number of heating and coaling cycles was determined using an air-quenching technique. Cold crushing strengths of the fired bricks were also performed to detect the maximum load-bearing capacity of the batch.

\section{Results}

The chemical composition of the used materials is mainly $\mathrm{Al}_{2} \mathrm{O}_{3}$ and $\mathrm{SiO}_{2}$, in addition to lesser amounts of fluxing and alkali oxides. Silica content decreases, while alumina content increases from clay to calcined bauxite (Table 1). The chemical composition of the clay shows that the major oxide content is silica (52.97\%) and alumina (29.07\%), with less frequent amounts of $\mathrm{TiO}_{2}(1.48 \%), \mathrm{Fe}_{2} \mathrm{O}_{3}$ (as total iron) $(3.92 \%)$, and alkali oxides $\left(\mathrm{CaO}, \mathrm{MgO}, \mathrm{Na}_{2} \mathrm{O}\right.$, and $\mathrm{K}_{2} \mathrm{O}$ ) all together less than $1.0 \%$; the sum of these oxides together is less than $6.0 \%$.
The calcined bauxite is used to enrich, adequately, these refractories; it is composed of $\mathrm{Al}_{2} \mathrm{O}_{3}$ up to $85.39 \%$, as well as $7.20 \% \mathrm{SiO}_{2}$ and nearly $7.0 \%$ total impurity oxides $\left(\mathrm{Fe}_{2} \mathrm{O}_{3}, \mathrm{TiO}_{2}, \mathrm{CaO}, \mathrm{MgO}, \mathrm{Na}_{2} \mathrm{O}\right.$, and $\mathrm{K}_{2} \mathrm{O}$ ). XRD patterns of the raw clay and calcined bauxite materials (Figs. 1 and 2) show that clay is composed mainly of kaolinite and halloysite as clay minerals in addition to quartz as a non-clay mineral. According to the XRD pattern (Fig. 2), the calcined bauxite is composed mainly of corundum $\left(\alpha-\mathrm{Al}_{2} \mathrm{O}_{3}\right)$ as mono-mineral; this indicates that the Chinese bauxite has been calcined at temperatures $>1600^{\circ} \mathrm{C}$. The plastic limit of the clay was determined as $21 \%$, the liquid limit was $31 \%$, and the plasticity was 10 ; this is attributed to the extremely fine quartz and kaolinite particles of the clay. Calcined bauxite is considered as a non-plastic material. The density of the clay and the calcined bauxite were detected as 1.17 and $3.29 \mathrm{~g} / \mathrm{cm}^{3}$, respectively (Table 2 ).

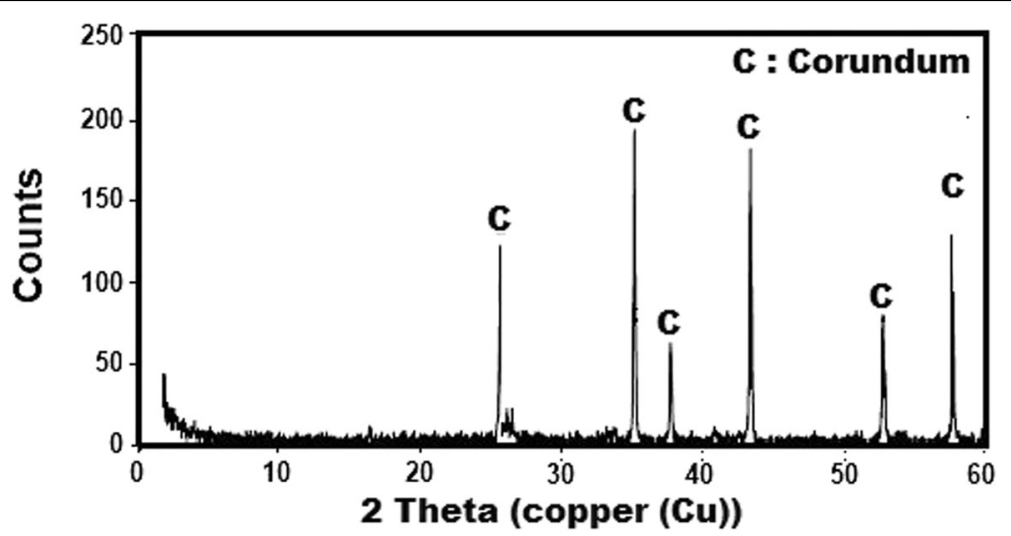

Fig. 2 XRD pattern of the calcined bauxite 
Table 2 Plasticity and density of the used materials

\begin{tabular}{llccc}
\hline & Bulk density $\mathrm{g} / \mathrm{cm}^{3}$ & Plastic limit & Liquid limit & Plasticity index \\
\hline Clay & 1.17 & 21 & 31 & 10 \\
$\begin{array}{l}\text { Calcined } \\
\text { bauxite }\end{array}$ & 3.29 & Non plastic & & \\
\hline
\end{tabular}

The designed batch from the clay and the calcined bauxite, as shown in Table 3, is composed of $20 \%$ kaolinitic clay and $80 \%$ calcined bauxite to give $~ 76 \%$ alumina and $\sim 17 \%$ silica. The total $\mathrm{Fe}_{2} \mathrm{O}_{3}$ and $\mathrm{TiO}_{2}$ contents in the designed batch in addition to the alkali oxides $\left(\mathrm{CaO}, \mathrm{MgO}, \mathrm{Na}_{2} \mathrm{O}\right.$, and $\left.\mathrm{K}_{2} \mathrm{O}\right)$, are7 about $7 \%$; this composition is responsible for the formation of a considerable silicate liquid phase at the firing temperature $\left(1350{ }^{\circ} \mathrm{C}\right)$. On cooling, the iron- and $\mathrm{TiO}_{2}$-rich silicate liquid phase solidified as an amorphous glassy phase.

Table 4 shows some of the technological properties of the high alumina designed and fired batch at $1350{ }^{\circ} \mathrm{C}$, in terms of bulk density, apparent porosity, linear shrinkage, thermal shock resistance, and cold crushing strength for the 3,5 , and $7 \%$ of phosphoric acid-containing batches. The batch containing 3\% phosphoric acid shows lower bulk density $\left(2.48 \mathrm{~g} / \mathrm{cm}^{3}\right)$ and apparent porosity (17.79\%) with little expansion percentage $(+0.07 \%)$. While for $5 \%$ concentration of phosphoric acid-containing batch, the maximum bulk density of the three batches is $2.55 \mathrm{~g} / \mathrm{cm}^{3}$ and decreased back again to $2.49 \mathrm{~g} / \mathrm{cm}^{3}$ for the $7 \%$ phosphorous acid-containing batch. The apparent porosities increased from 18.51 to $21.65 \%$ in the $5 \%$ and $7 \%$ phosphorous acid-containing batches respectively; however, the linear shrinkage remained more or less constant ( 0.18 and $0.17 \%$, respectively).

Table 3 Composition of the designed high alumina batch

\begin{tabular}{lllll}
\hline Oxide $\%$ & 20 g clay & $\begin{array}{l}80 \mathrm{~g} \text { calcined } \\
\text { bauxite }\end{array}$ & $\begin{array}{l}\text { High alumina } \\
>72 \% \mathrm{Al}_{2} \mathrm{O}_{3}\end{array}$ & $\begin{array}{l}\text { On calcined } \\
\text { calculation }\end{array}$ \\
\hline $\mathrm{SiO}_{2}$ & 10.59 & 5.76 & 16.35 & 16.76 \\
$\mathrm{Al}_{2} \mathrm{O}_{3}$ & 5.81 & 68.31 & 74.12 & 75.97 \\
$\mathrm{TiO}_{2}$ & 0.29 & 3.26 & 3.55 & 3.64 \\
$\mathrm{Fe}_{2} \mathrm{O}_{3}$ & 0.78 & 1.96 & 2.74 & 2.81 \\
$\mathrm{CaO}$ & 0.10 & 0.06 & 0.16 & 0.16 \\
$\mathrm{MgO}$ & 0.04 & 0.13 & 0.17 & 0.17 \\
$\mathrm{Na}_{2} \mathrm{O}$ & 0.01 & 0.02 & 0.03 & 0.03 \\
$\mathrm{~K}_{2} \mathrm{O}$ & 0.06 & 0.22 & 0.28 & 0.29 \\
$\mathrm{SO}_{3}$ & 0.15 & - & 0.15 & 0.15 \\
$\mathrm{LOI}$ & 2.12 & - & 2.12 & - \\
$\mathrm{Total}$ & 19.97 & 79.712 & 99.67 & 99.98 \\
\hline
\end{tabular}

The load-bearing capacity values, in terms of cold crushing strengths, decrease, drastically, from 1122, 806 , to $665 \mathrm{~kg} / \mathrm{cm}^{2}$ for 3,5 , and $7 \%$ of phosphoric acid-containing batches, respectively. For thermal shock resistance (expressed by the resistance to a successive heating and air quenching cycles), all the prepared batches exhibit high thermal shock resistance, as they successfully passed more than 30 cycles of sudden firing at $1000^{\circ} \mathrm{C}$ followed by sudden cooling in air with no sign of disintegration and/or fracturing. These results satisfy the required thermal shock resistance of such batches for various applications, as given in the Egyptian Standard ES-41342003 and the European Standard DIN EN 12478-1998 (Serry et al. 2006 and Serry and El-Maghraby 2006).

\section{Discussion}

The chemical and mineralogical compositions of the starting materials as well as the fired products, formed phases, and microstructures were confirmed by XRF, XRD, and SEM. Several studies were carried out to estimate the forms of mullite and corundum and their temperature, e.g., Sainz et al. (2000), Schneider et al. (1994), and Xiaohong et al. (2017).

It is observed that, on increasing of the phosphoric acid percentages, there is a noticeable increase in apparent porosities, while the cold crushing strengths decrease. The bulk densities as well as the linear shrinkages show slight changes from lower density, related to little expansion at 3\% phosphoric acid content, to higher density with the maximum shrinkage at $5 \%$ phosphoric acid batch. It is also noticed that the batches containing the higher percentages of phosphoric acid exhibit higher porosities and lower cold crushing strengths.

The 3\% phosphoric acid concentration batch, fired at $1350{ }^{\circ} \mathrm{C}$, as it exhibited the highest cold crushing strength, was selected for further identification in order to reveal its mineral composition and microstructure using XRD, SEM, and EDAX.

It is clear from Fig. 3 that mullite is the essential formed mineral with subordinate amounts of corundum, while berlinite $\left(\mathrm{AlPO}_{4}\right)_{3}$, quartz, and cristobalite are minor constituents.

The microstructure of the $3 \%$ phosphoric acid concentration batch fired at $1350{ }^{\circ} \mathrm{C}$ is shown in Fig. 4; the main recorded phase is mullite, as shown in Fig. 4a, it appears as bright inter locking prismatic lathes condensed with each other. The EDAX analysis shows that alumina and silica are the main oxides with minor amounts of iron and titanium oxide solid solution. 
Table 4 Properties of high alumina batch fired at $1350^{\circ} \mathrm{C}$

\begin{tabular}{llllll}
\hline Phosphoric acid \% & $\begin{array}{l}\text { Bulk density } \\
\mathrm{g} / \mathrm{cm}^{3}\end{array}$ & $\begin{array}{l}\text { Apparent } \\
\text { porosity } \%\end{array}$ & $\begin{array}{l}\text { Linear } \\
\text { shrinkage \% }\end{array}$ & $\begin{array}{l}\text { Thermal shock } \\
\text { resistance } \\
\text { No. of cycles }\end{array}$ & $\begin{array}{l}\text { Cold crushing } \\
\text { strength } \\
\mathrm{kg} / \mathrm{cm}^{2}\end{array}$ \\
\hline $3 \%$ & 2.48 & 17.79 & +0.07 & $>30$ & 1122 \\
$5 \%$ & 2.55 & 18.51 & 0.18 & $>30$ & 806 \\
$7 \%$ & 2.49 & 21.65 & 0.17 & $>30$ & 665 \\
\hline
\end{tabular}

Figure 4b shows large gray cube-like corundum crystals, composed mainly of $\mathrm{Al}_{2} \mathrm{O}_{3}$. In addition to little amounts of silica, this is mainly due to the mullite corundum interferences.

The solid solution of mullite, phosphate phase and liquid phase of iron, titanium, and alkali oxides is illustrated in Fig. 4c. No silica minerals were detected probably due to their minor content or interference with mullite and glassy phase.

Generally, the selected batch has an acceptable bulk density, and cold crushing strength values higher than the requirements of the Egyptian Standard ES-41342003 and the European Standard DIN EN 12478-1998 (Serry et al. 2006 and Serry and El-Maghraby 2006); furthermore, its apparent porosity exists within the acceptable range of such standard refractories $(<20.0 \%)$. This is usually attributed to the presence of the highly refractory phases (corundum and mullite); in addition, the glassy phase is thought to be the main factor that improves the load-bearing capacity of this mullite batch.

Batch of 3\% of phosphoric acid concentrations could be successfully used in lining different types of industrial furnaces, including both iron and steel furnaces, as well as nonferrous, petrochemical, rotary-cement, and lime kilns.

\section{Conclusions}

- Egyptian clay of Al-Ogybabe area, northeast Aswan city, Egypt, in addition to China calcined bauxite were used to produce batch of high alumina refractories $>72 \% \mathrm{Al}_{2} \mathrm{O}_{3}$.

- Mineral and chemical composition of the clay confirms that the kaolinite and halloysite are the main clay minerals, while quartz is the non-clay mineral, and the alumina and silica contents are $29.07 \%$ and $52.97 \%$, respectively.

- The XRD and XRF data of the calcined bauxite indicate that it is composed mainly of corundum $\left(\alpha-\mathrm{Al}_{2} \mathrm{O}_{3}\right)$ which exists as mono-mineral phase, and the alumina content is $85.39 \%$, with a lesser amount of silica reaching up to $7.20 \%$.

- A high alumina batch of $76 \%$ alumina was prepared by mixing of $20 \%$ clay and $80 \%$ calcined bauxite. Three concentrations of phosphoric acid, 3, 5, and $7 \%$, were added to the prepared batch to form three different batches with different phosphoric acid concentrations.

- The three batches were fired at $1350{ }^{\circ} \mathrm{C}$ for $1 \mathrm{~h}$. The densification parameters, cold crushing strength, and thermal shock resistance were measured.

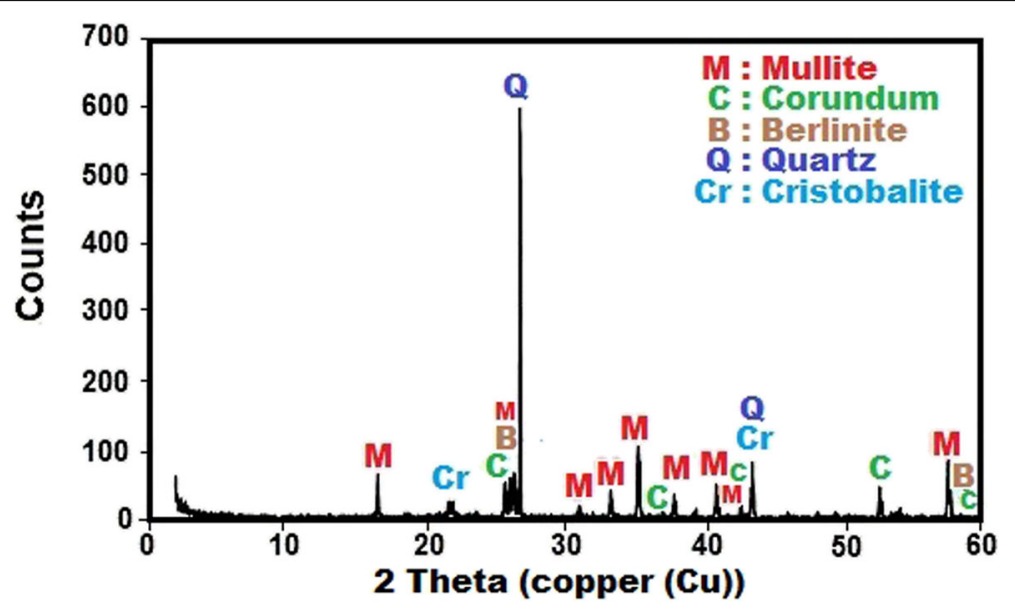

Fig. 3 XRD pattern of the $3 \%$ phosphoric acid batch fired at $1350^{\circ} \mathrm{C}$ for $1 \mathrm{~h}$ 


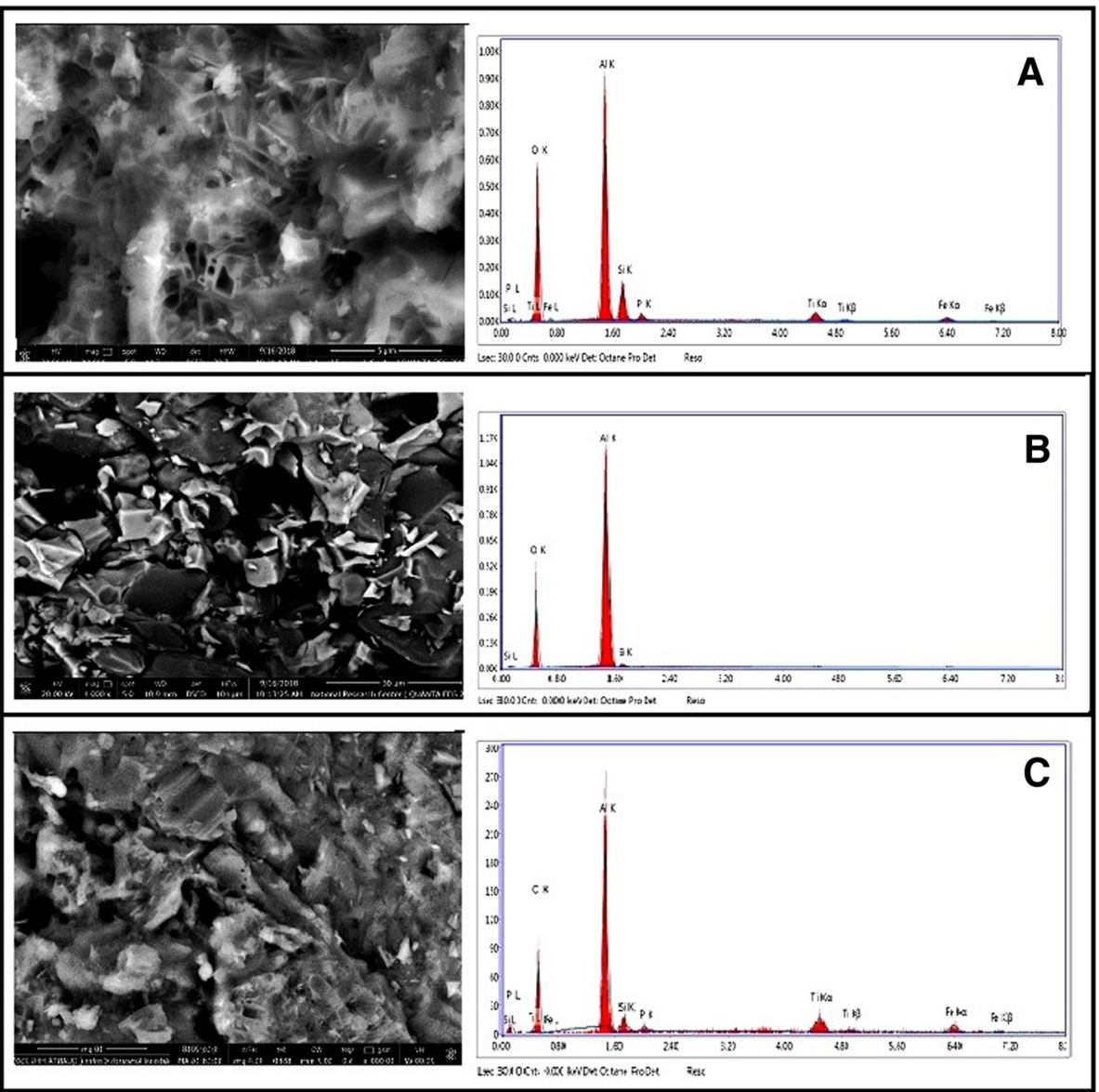

Fig. 4 The microstructure of the $3 \%$ phosphoric acid concentration batch fired at $1350^{\circ} \mathrm{C}$. a Bright interlocking prismatic mullite lathes condensed with each other; alumina and silica are the main oxides with minor amounts of iron and titanium oxide solid solution. $\mathbf{b}$ Cube-like corundum crystals composed mainly of $\mathrm{Al}_{2} \mathrm{O}_{3}$, with little amounts of silica, mainly due to the mullite corundum interferences. c Solid solution of mullite, phosphate phase and liquid phase of iron, titanium, and alkali oxides

- The batch of $3 \%$ phosphoric acid concentration was selected to study its mineral and microstructure composition using XRD as well as SEM and EDX.

- The mineral composition of the selected fired batch revealed that mullite is the main phase, with subordinate amounts of corundum, berlinite, quartz, and cristobalite as minor constituents. The microstructure of the selected batch ensures that mullite is the essential formed mineral.

- SEM and EDAX confirmed that mullite and corundum are the main mineral phases associated with minor phosphate minerals, while the fluxing and alkali oxides together with some alumina and silica form liquid phase which is responsible for the densification of the batch.

\section{Acknowledgements}

The present authors are deeply grateful to the Marble and Granite Testing Laboratory Unit and Geo-mechanical Consultant Unit, National Research

Centre, Egypt, for their support during the preparation of the present article.
Funding

Funding was received from the Marble and Granite Lab. Unit and Geo-mechanical Consulting Unit National Research Centre, Cairo, Egypt.

Availability of data and materials

The authors declare that the work data and materials are available.

\section{Authors' contributions}

MSE-M, AIMI, and BNE-DAS contribute in field, mineralogy and geochemistry, physical parameters, and application works. MSE-M contributes in refractory applications. All authors read and approved the final manuscript.

Ethics approval and consent to participate

The authors declare that the work is ethically approved and consent to participate was obtained.

\section{Consent for publication}

The authors declare that the work has consent for publication.

Competing interests

The authors declare that they have no competing interests.

\section{Publisher's Note}

Springer Nature remains neutral with regard to jurisdictional claims in published maps and institutional affiliations. 


\section{Author details}

${ }^{1} G$ Geological Sciences Department, National Research Centre, P.O. 12622, 33 El Buhouth St. Dokki, Giza, Egypt. ${ }^{2}$ Ceramics, Refractories and Building Materials Department, National Research Centre, P.O. 12622, 33 El Buhouth St. Dokki, Giza, Egypt.

Received: 26 September 2018 Accepted: 11 November 2018 Published online: 23 November 2018

\section{References}

BS 1377 (1975) Moisture content and index tests, London, pp 50-100

Carniglia SC, Barna GL (1992) Handbook of industrial refractories technology. Noyes Publications, New Jersy

Chesters JH (1973) Refractories: production and properties. Iron and Steel Institute, London

Chesters JH (1974) Steel plant refractories. Iron and Steel Institute, London Elmaghraby MS, Ismail AIM (2016) Utilization of some Egyptian waste kaolinitic sand as grog for bricks and concrete. Silicon 8:299-307

Grim RE (1968) Clay mineralogy, 2nd edn. Mc Graw Hill Book Co., Inc, New York Kingrey WD, Bown H, Uhlamann DR (1976) Introduction to ceramics, 2nd edn. Wiley, New York

Konta J (1979) Properties of ceramic raw materials. monograph 1.1.4. in Ceramic Monographs: Handbook of Ceramics, VerlagShmid GmbH, Freibergi. Brg

Luza AP, Gomesb DT, Pandolfellia VC (2015) High-alumina phosphate-bonded refractory castables:Al(OH)3 sources and their effects. Ceram Int 41:9041-9050

Routschka G (ed) (2004) Pocket manual of refractories, 2nd edn. Vulkan-Verlag, Essen

Sadik C, El Amrani I, Albizane A (2014) Recent advances in silica-alumina refractory: a review. J Asian Ceramic Soc 2:83-96

Sahnoun RD, Bouaziz J (2012) Sintering characteristics of kaolin in the presence of phosphoric acid binder. Ceram Int 38:1-7

Sainz MA, Serrano FJ, Amigo JM, Bastida J, Caballero A (2000) XRD microstructural analysis of mullites obtained fromkaolinite \pm alumina mixtures. J Eur Ceram Soc 20:403

Schacht CA (2004) Refractories handbook. Marcel Dekker, Inc, New York-Basel Schneider H, Okada K, Pask JA (1994) Mullite and mullite ceramics. Wiley, Chichester Serry MA, El-Maghraby MS (2006) Egyptian refractory raw materials. A review. Ind Ceram 26(1):37-51

Serry MA, El-Maghraby MS, Salama SZ (2006) Assessment of Egyptian shaped alumino-silicate refractories from Egyptian raw materials. Am Ceram Soc Bull 85(9):9201-9206

Shaw K (1972) Refractories and their uses. Applied Science Publishers, London Trepalina YN, Evtushenko El, Doroganov VA (2016) Mechanochemically activated phosphate-containing refractory composite materials. Refract Ind Ceram 57(1):42

Xiaohong X, Jingwen L, Jianfeng W, Zhaohui T, Linlin C, Yao L, Chenglong L (2017) Preparation and thermal shock resistance of corundum-mullite composite ceramics from andalusite. Ceram Int 43(2):1762-1767

\section{Submit your manuscript to a SpringerOpen ${ }^{\circ}$ journal and benefit from:}

- Convenient online submission

- Rigorous peer review

- Open access: articles freely available online

- High visibility within the field

- Retaining the copyright to your article

Submit your next manuscript at $\boldsymbol{\nabla}$ springeropen.com 